\title{
Graft patency after off-pump coronary artery bypass surgery is inferior even with identical heparinization protocols: Results from the Danish On-pump Versus Off-pump Randomization Study (DOORS)
}

Kim Houlind, MD, PhD,,${ }^{\mathrm{a} b} \mathrm{~b}$ Morten Fenger-Grøn, MSc, ${ }^{\mathrm{c}}$ Susanne J. Holme, MD, ${ }^{\mathrm{d}}$ Bo J. Kjeldsen, MD, PhD, Susanne N. Madsen, MD, ${ }^{\mathrm{f}}$ Bodil S. Rasmussen, MD, PhD, ${ }^{\mathrm{g}}$ Mogens H. Jepsen, MD, ${ }^{\mathrm{a}}$ Jan Ravkilde, MD, DMSc, ${ }^{\text {h,i }}$ Jens Aaroe, MD, DMSc, ${ }^{\text {h }}$ Peter Riis Hansen, MD, DMSc, ${ }^{j}$ Henrik Steen Hansen, MD, DMSc, ${ }^{\mathrm{k}}$ and Poul Erik Mortensen, MD, ${ }^{\mathrm{e}}$ for the DOORS Study Group

Objective: To determine whether graft patency after on-pump and off-pump coronary artery bypass surgery is similar when performed using the same heparinization protocol.

Methods: In a randomized, controlled, multicenter trial, 900 patients more than 70 years of age received either on-pump or off-pump coronary artery bypass surgery. Heparin was given to achieve an activated clotting time of 400 seconds before arteriotomy in both groups. After the procedure, protamine sulfate was given to revert the activated clotting time to less than 120 seconds. Coronary angiography was performed 6 months after the operation and graft patency was assessed by independent blinded observers.

Results: A total of 481 patients underwent angiography. In the off-pump group, 561 (79\%) of 710 grafts were open, $65(9 \%)$ were stenotic, and $84(12 \%)$ were occluded. In the on-pump group, $549(86 \%)$ of 650 grafts were open, $38(5 \%)$ were stenotic, and $63(9 \%)$ were occluded. The difference between the proportion of open grafts was statistically significant in favor of on-pump surgery $(P=.01)$. The proportion of open left internal thoracic artery grafts was $95 \%$ in both groups. Perioperative use of intracoronary shunts did not increase the risk of stenosis of the coronary artery distal to the anastomosis.

Conclusions: Despite comparable heparinization, graft patency after off-pump surgery was inferior to that after on-pump surgery. (J Thorac Cardiovasc Surg 2014;148:1812-9)

From the Department of Cardiothoracic Surgery, ${ }^{a}$ Skejby Hospital, Aarhus University Hospital, Aarhus; Institute of Regional Heath Services Research, ${ }^{\mathrm{b}}$ University of Southern Denmark, Odense; Research Unit for General Practice, ${ }^{\mathrm{c}}$ Aarhus University, Aarhus; Department of Cardiothoracic Surgery, ${ }^{\mathrm{d}}$ Gentofte Hospital, Gentofte; Department of Cardiothoracic Surgery, ${ }^{\mathrm{e}}$ Odense University Hospital, Odense; Center for Cardiovascular Research, ${ }^{\mathrm{f}}$ Department of Cardiothoracic Surgery, Aalborg University Hospital, Aalborg; Department of Anesthesia, ${ }^{\mathrm{g}}$ Aalborg University

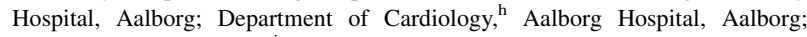
Department of Cardiology, ${ }^{\mathrm{i}}$ Skejby Hospital, Aarhus University Hospital, Aarhus; Department of Cardiology, ${ }^{\mathrm{j}}$ Gentofte Hospital, Gentofte; and Department of Cardiology, ${ }^{\mathrm{k}}$ Odense University Hospital, Odense, Denmark.

This work was supported by the Danish Heart Foundation, Danish Centre for Health Technology Assessment, Danish Research Council for Health Sciences, Tove and John Girott's Foundation, Medtronic, Guidant, and Getinge. The sponsors of this trial were not involved in the study design, data collection, data analysis, data interpretation, or writing of the report.

Disclosures: Bo J. Kjeldsen reports consulting fees from Edwards Lifesciences. All other authors have nothing to disclose with regard to commercial support.

Clinical Trial Registration: http://www.clinicaltrials.gov; unique identifier, NCT00123981.

Received for publication Sept 23, 2013; revisions received Jan 16, 2014; accepted for publication Feb 4, 2014; available ahead of print March 7, 2014.

Address for reprints: Kim Houlind, MD, PhD, Department of Vascular Surgery, Kolding Hospital, Little Belt Hospital, Skovvangen 2-8, 6000 Kolding, Denmark (E-mail: kim.houlind@iekf.au.dk).

0022-5223/\$36.00

Copyright (c) 2014 by The American Association for Thoracic Surgery

http://dx.doi.org/10.1016/j.jtcvs.2014.02.024
Supplemental material is available online.

Coronary artery bypass grafting has traditionally been performed with the use of cardiac arrest and extracorporeal cardiopulmonary bypass (conventional coronary artery bypass $[\mathrm{CCABG}])$. However, some concern has been raised with regard to the safety of CCABG. Since the mid-1990s, therefore, a significant proportion of coronary artery bypass operations have been performed on the beating heart (off-pump coronary artery bypass, OPCAB). It has been suggested that the risk of perioperative stroke could be reduced by avoiding manipulation of the aorta, ${ }^{1}$ although this was not confirmed by recent large-scale trials. ${ }^{2-4}$ Smaller trials have documented a decreased inflammatory response, ${ }^{5-7}$ less bleeding, ${ }^{8-10}$ lower risk of atrial fibrillation, ${ }^{8}$ smaller release of biochemical markers of myocardial injury, ${ }^{10-12}$ and lower $\operatorname{costs}^{13-15}$ related to OPCAB compared with CCABG.

On the other hand, the efficacy of OPCAB has been questioned. Most studies ${ }^{2-4,14}$ have found that OPCAB patients receive fewer grafts and that a lower proportion of 


\section{Abbreviations and Acronyms \\ $\mathrm{ACT}=$ activated clotting time \\ $\mathrm{CCAB}=$ conventional coronary artery bypass \\ DOORS $=$ Danish On-pump Versus Off-pump Randomization Study \\ LAD $=$ left anterior descending \\ ITA $=$ internal thoracic artery \\ LVEF $=$ left ventricular ejection fraction \\ $\mathrm{OPCAB}=$ off-pump coronary artery bypass}

OPCAB patients are fully revascularized compared with CCABG patients. Several studies have also shown poorer graft patency at follow-up after OPCAB..$^{3,14,16-18}$

Several differences between off-pump and on-pump surgery may contribute to a lower graft patency in off-pump patients. The on-pump technique offers a bloodless, immobile field for performing the anastomoses, whereas $\mathrm{OPCAB}$ surgery is more technically challenging. Also, although cardiopulmonary bypass is a cause for hemodilution and platelet dysfunction, a hypercoagulable state may be present in patients after OPCAB surgery. ${ }^{19-21}$ Despite this observation, most centers give lower intraoperative doses of heparin for OPCAB than CCABG. ${ }^{22,23}$ In this regard, it is interesting that Uva and colleagues ${ }^{18}$ in a randomized controlled trial, found a significantly lower crude graft patency rate after off-pump surgery compared with onpump surgery, but failed to find a significant difference after adjusting for heparin dose.

A drawback of the earlier studies is the lack of control of antiplatelet therapy. Randomized trials point toward a clinical benefit of clopidogrel in addition to aspirin after surgery, especially for OPCAB patients. ${ }^{24}$ This treatment (clopidogrel) was either not used, not controlled for, or not reported in the earlier trials. ${ }^{2,3,9,14,18}$

The Danish On-pump Off-pump Randomization Study (DOORS) comprised 900 patients of more than 70 years of age. ${ }^{4,25}$ To exclude the effects of different heparinization protocols and differences in antiplatelet therapy, both these treatments were standardized and identical in the 2 study groups. The aim of the current study was to examine whether graft patency after off-pump surgery was equal to the results for on-pump surgery.

\section{METHODS}

\section{Design and Participants}

Details of the design of the DOORS study have been given elsewhere. ${ }^{25}$ The names of the investigators are listed in Appendix E1. Nine hundred patients who were 70 years of age or older and who were admitted for nonemergency surgical revascularization at 1 of the 4 participating centers were consecutively screened for participation in the study (Figure 1). All participating surgeons were consultants experienced in multivessel $\mathrm{CCABG}$ and $\mathrm{OPCAB}$ surgery. Each had previously performed a minimum of $25 \mathrm{OPCAB}$ operations with grafts to the circumflex territory before entering the study. Trainees were not allowed to be the primary surgeon for any procedure.

\section{Consent and Inclusion Procedure}

The patients gave written consent after provision of written and oral information. The study protocol was approved by the local ethics committee.

\section{Randomization and Masking}

Online randomization was performed. Block randomization was performed in blocks of 6 stratified by treating center. Treatment was not masked. Before randomizing, the surgeon responsible was requested to submit a plan indicating the specific target vessels to be grafted.

\section{Interventions}

Anesthesia, cardiopulmonary bypass, surgery, and postoperative care were performed according to detailed protocols. ${ }^{25}$ All operations were performed through a full median sternotomy, and all patients in the CCABG group were operated with aortic crossclamping and cardioplegic arrest. For OPCAB, exposure was achieved with deep pericardial anchoring sutures fixing a supporting gauze and using both apical and local stabilizing suction devices (Octopus Tissue Stabilizer; Medtronic Inc, Minneapolis, Minn) or CTS Axius Guidant Stabilizer System (Guidant Corporation, Santa Clara, Calif). Use of intracoronary shunts was favored when this was technically possible. Application of coronary occlusion snares was permitted within the protocol only proximal, not distal, to the anastomotic site. The use of shunts or snares was only applied for OPCAB patients. Graft patency was assessed at the end of the procedure using a Transit Time Flow Meter (Medistim, Oslo, Norway). A revision was performed if the flow or pulsatility index was deemed unacceptable by the surgeon.

All patients were treated with clopidogrel $75 \mathrm{mg} / \mathrm{d}$ for 3 months postoperatively, except for patients treated with coumarins for other indications. Statins and acetyl salicylic acid were given to all patients unless specifically contraindicated.

For both OPCAB and CCABG operations, heparin was given at a dose sufficient to achieve an activated clotting time (ACT) of 400 seconds before opening the pericardium. For OPCAB operations, the anticoagulation was reverted using protamine sulfate until the ACT was brought back to less than 120 seconds after performing the anastomoses. Similarly, for CCABG operations, heparinization was reverted using protamine to an ACT level of less than 120 seconds after decannulation.

\section{Follow-up}

Six months after surgery, patients were invited to have a control coronary angiography. An attempt was made to inject contrast and visualize all grafts in 2 orthogonal planes after administration of nitroglycerin. All examinations were assessed in a blinded manner by 2 of 4 experienced interventional cardiologists (J.R., J.A, P.R.H., H.S.H.), who assessed the proximal anastomosis, the shaft of the graft, and the distal anastomosis, and rated it according to the FitzGibbon criteria ${ }^{26}$ as A (open), B ( $>50 \%$ stenotic), or O (occluded), or as "not sufficiently well visualized to decide." To evaluate whether the use of proximal snares or intracoronary shunts caused damage to the native coronary vessels, the section of the coronary artery $1 \mathrm{~cm}$ proximal and $1 \mathrm{~cm}$ distal to the anastomosis was also assessed. Controversies were settled by conference.

\section{Statistics}

When comparing graft patency between OPCAB and CCABG patients, the least favorable grading of either the proximal anastomosis, the shaft, or the distal anastomosis was used. For example, a graft with a FitzGibbon grading of B for the proximal anastomosis, A for the shaft, and A for the distal anastomosis received an overall $\mathrm{B}$ grade. ${ }^{26}$ 


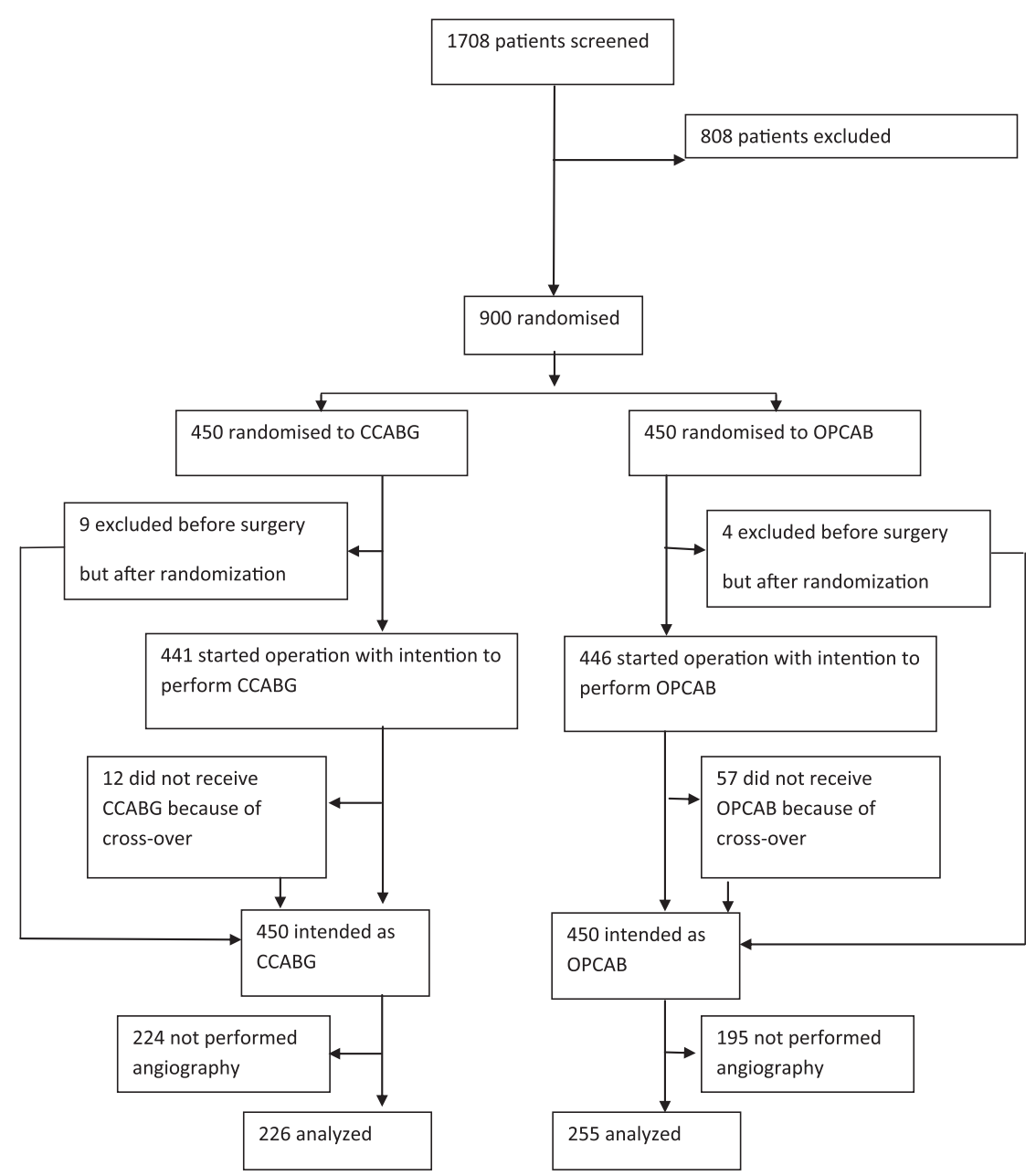

FIGURE 1. Study flowchart. $C C A B G$, Conventional coronary artery bypass grafting; $O P C A B$, off-pump coronary artery bypass.

When comparing the number of grafts performed and the number of grafts planned, the Wilcoxon signed rank test was applied. For comparison of baseline characteristics and secondary end points, the Pearson $\chi^{2}$ test $(P)$, the Mann-Whitney rank test $(\mathrm{r})$, or the Fisher exact test $(\mathrm{F})$ was used as appropriate.

Crude and adjusted risk differences were calculated between OPCAB or CCABG, depending on whether revision of anastomosis was required or not, coronary vessel territory, graft material, type of proximal anastomosis, and position in sequencing grafts. The differences were assessed using a binomial regression model; that is, a generalized linear model from the Bernoulli family using identity links. Cluster-robust variance estimation was performed to account for the expected dependence between vessels within the same patient. In an additional post hoc analysis, the use of proximal snaring and intracoronary shunts was also included. An analysis of the propensity to choose to have follow-up angiography with inclusion of key variables was performed. Analyses were performed according to intention to treat using STATA (Stata Corporation, College Station, Tex).

\section{RESULTS}

The baseline clinical characteristics of the patients who underwent coronary angiography at 6 months follow-up are given in Table 1. The corresponding data for the entire group of enrolled patients have been reported earlier. ${ }^{4}$ Compared with the patient groups enrolled originally, a higher proportion of male patients $(59 \%$ vs $42 \%)$ and a higher proportion of OPCAB patients $(58 \%$ vs $51 \%)$ underwent the coronary angiography. The groups examined were, however, balanced with regard to age, comorbidities, and use of medication. A total of 57 patients assigned to OPCAB were converted to CCABG. All conversions were performed before the undertaking any anastomoses. The reasons were hemodynamic instability $(n=27)$ or difficulties with exposure of coronary vessels $(n=30)$. Twelve patients had their operations converted from CCABG to $\mathrm{OPCAB}$, all because of heavily calcified aortas.

\section{Mortality}

Six months after surgery, mortality was $21(4.7 \%)$ in the on-pump group and $19(4.2 \%)$ in the off-pump group $(P=.75)$. Causes of mortality were not recorded, but 3 of the CCABG patients and 1 of the OPCAB patients who died within the 6-month follow-up period had a stroke 
TABLE 1. Risk factors and comorbidities

\begin{tabular}{|c|c|c|c|}
\hline & $\begin{array}{l}\text { CCABG } \\
(n=226)\end{array}$ & $\begin{array}{l}\text { OPCAB } \\
(\mathbf{n}=\mathbf{2 5 5})\end{array}$ & $P$ value \\
\hline Age, median y (IQR) & $75(72-78)$ & $74(72-77)$ & $.21(\mathrm{r})$ \\
\hline Male sex, $\%$ & 84 & 81 & $.48(\mathrm{P})$ \\
\hline Left main stenosis $>50 \%, \%$ & 43 & 51 & $.10(\mathrm{P})$ \\
\hline One-vessel disease, $\%$ & 2 & 3 & \\
\hline Two-vessel disease, $\%$ & 21 & 16 & \\
\hline Three-vessel disease, $\%$ & 76 & 81 & $.30(\mathrm{r})$ \\
\hline \multicolumn{4}{|l|}{ LVEF, \% } \\
\hline$\geq 50 \%$ & 70 & 73 & \\
\hline$\geq 30 \%,<50 \%$ & 25 & 23 & \\
\hline$<30 \%$ & 6 & 5 & $.76(\mathrm{r})$ \\
\hline \multicolumn{4}{|l|}{ Previous MI, \% } \\
\hline Within $90 \mathrm{~d}$ before operation & 23 & 23 & \\
\hline $\begin{array}{l}\text { Earlier than } 90 \mathrm{~d} \text { before } \\
\text { operation }\end{array}$ & 23 & 19 & \\
\hline Never & 54 & 58 & $.59(\mathrm{P})$ \\
\hline Neurologic dysfunction, $\%$ & 4 & 5 & $.88(\mathrm{P})$ \\
\hline COPD, \% & 7 & 7 & $.86(\mathrm{P})$ \\
\hline PVD, \% & 12 & 11 & $.96(\mathrm{P})$ \\
\hline $\begin{array}{l}\text { Previous percutaneous coronary } \\
\text { intervention, } \%\end{array}$ & 15 & 17 & $.51(\mathrm{P})$ \\
\hline Diabetes, $\%$ & 16 & 22 & $.15(\mathrm{P})$ \\
\hline Hypertension (medicated), \% & 70 & 68 & $.69(\mathrm{P})$ \\
\hline Atrial fibrillation, $\%$ & 6 & 5 & $.90(\mathrm{P})$ \\
\hline \multicolumn{4}{|l|}{ Smoking, \% } \\
\hline Current & 23 & 26 & \\
\hline Previous & 57 & 47 & \\
\hline Never & 20 & 27 & $.09(\mathrm{r})$ \\
\hline Obesity $\left(\mathrm{BMI}>30 \mathrm{~kg} / \mathrm{m}^{2}\right), \%$ & 22 & 20 & $.50(\mathrm{P})$ \\
\hline $\begin{array}{l}\text { Hemoglobin, median } \mathrm{mmol} / \mathrm{L} \\
\text { (IQR) }\end{array}$ & $8.4(8.0-9.0)$ & $8.6(8.0-9.1)$ & $.22(r)$ \\
\hline $\begin{array}{l}\text { Serum creatinine, median } \\
\mathrm{mmol} / \mathrm{L}(\mathrm{IQR})\end{array}$ & $94(82-111)$ & $94(81-109)$ & $.55(\mathrm{r})$ \\
\hline Unstable angina (nitro-iv), \% & 1 & 3 & $.14(\mathrm{P})$ \\
\hline \multicolumn{4}{|l|}{ Medication, $\%$} \\
\hline Aspirin & 90 & 94 & $.11(\mathrm{P})$ \\
\hline$\beta$-Blockers & 75 & 76 & $.67(\mathrm{P})$ \\
\hline Statins & 89 & 89 & $.96(\mathrm{P})$ \\
\hline ACE inhibitors & 45 & 42 & $.49(\mathrm{P})$ \\
\hline Calcium antagonists & 36 & 33 & $.61(\mathrm{P})$ \\
\hline Nitrates & 45 & 46 & $.87(\mathrm{P})$ \\
\hline Diuretics & 41 & 39 & $.67(\mathrm{P})$ \\
\hline Coumarins & 15 & 15 & $.87(\mathrm{P})$ \\
\hline Digitalis & 4 & 5 & $.31(\mathrm{P})$ \\
\hline Clopidogrel & 37 & 32 & $.25(\mathrm{P})$ \\
\hline Antiarrythmics & 4 & 6 & $.26(\mathrm{P})$ \\
\hline
\end{tabular}

$I Q R$, Interquartile range; $L V E F$, left ventricular ejection fraction; $M I$, myocardial infarction; $C O P D$, chronic obstructive pulmonary disease; $P V D$, peripheral vascular disease; $B M I$, body mass index; $A C E$, angiotensin-converting enzyme; $C C A B G$, conventional coronary artery bypass grafting; $O P C A B$, off-pump coronary artery bypass.

within the first 30 postoperative days; 1 of the CCABG patients and 5 of the OPCAB patients who died within the 6-month follow-up period had a myocardial infarction within the first 30 postoperative days.

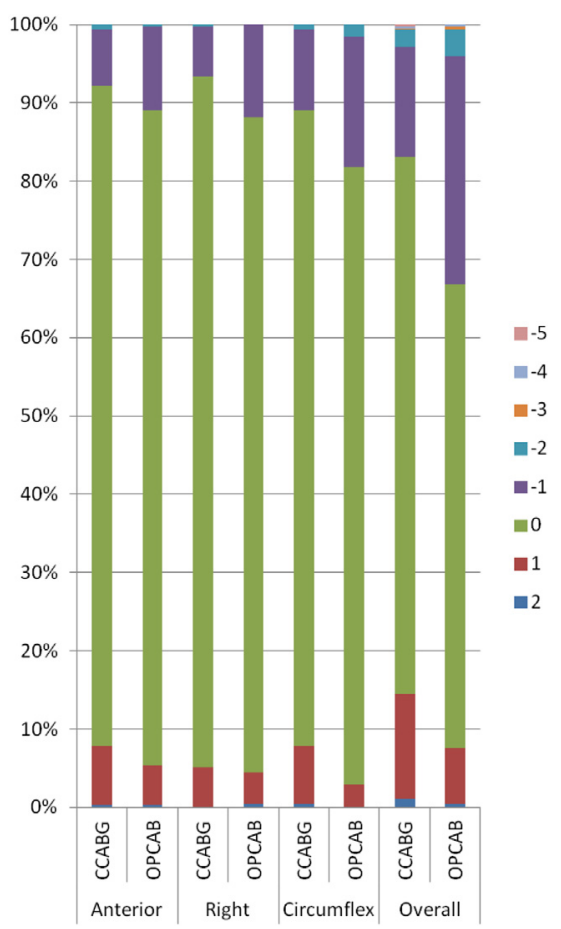

FIGURE 2. Number of realized grafts as percentages of the number of preoperatively projected grafts divided in treatment groups and coronary territories. Anterior: Left anterior descending artery territory, Right: Right coronary artery territory, Circumflex: Circumflex artery territory. $C C A B G$, Conventional coronary artery bypass grafting; $O P C A B$, off-pump coronary artery bypass.

\section{Number of Grafts}

The preoperative plans stipulated 1408 grafts in the CCABG group and 1441 in the OPCAB group. A total of 1383 grafts were performed in the CCABG patients and 1309 in the OPCAB patients (between-group comparison of the number of grafts performed compared with the number of grafts planned, $P=.039$ ). As shown in Figure 2, this tendency toward fewer grafts being performed at OPCAB operations was present for all coronary territories. The proportion of patients who received fewer grafts than planned was $32 \%$ among OPCAB patients who underwent angiographic follow-up and 36\% among those who did not undergo this examination. For the CCABG group, the number was $17 \%$ irrespective of whether they underwent follow-up angiography or not $(P=.69)$.

\section{Graft Patency}

After 6 months, 481 patients ( $56 \%$ of the 860 survivors) underwent control angiography. A total of 1475 grafts were cannulated and 1360 grafts were visualized well enough for the cardiologists to reach a decision on graft patency. Among OPCAB patients, 710 grafts were graded and of these, $561(79 \%)$ were graded as open, $65(9 \%)$ were stenotic, and $84(12 \%)$ were occluded. In the CCABG group, $549(86 \%)$ of 650 grafts were open, $38(5 \%)$ were stenotic, 


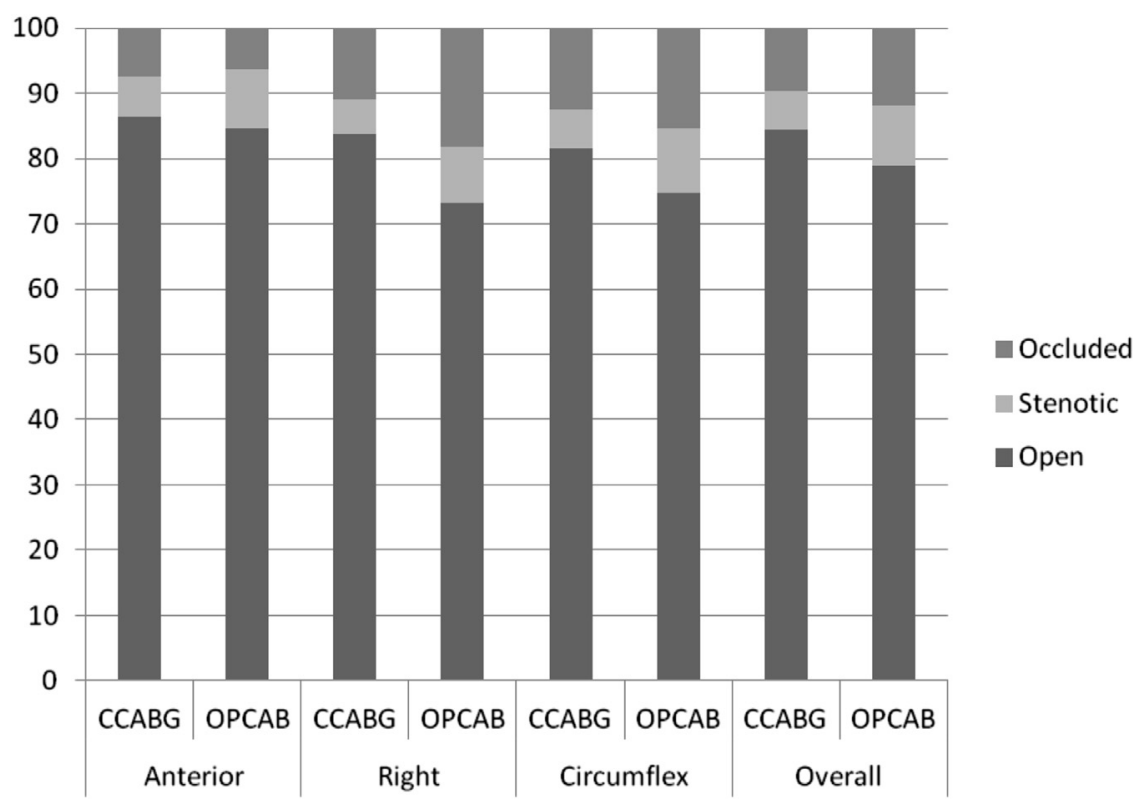

FIGURE 3. Percentage of occluded, stenotic, and open grafts in each territory. $C C A B G$, Conventional coronary artery bypass grafting; $O P C A B$, off-pump coronary artery bypass. Anterior: Left anterior descending artery territory; Right: Right coronary artery territory; Circumflex: Circumflex artery territory.

and $63(9 \%)$ were occluded. Although the difference between the number of totally occluded grafts did not reach statistical significance $(P=.20)$, the difference between the fraction of open (ie, nonoccluded) and nonstenotic grafts was statistically significant in favor of CCABG $(P=.01)$.

Graft patencies for each coronary territory are shown in Figure 3. Grafts to the anterior territory had high patency, whereas the patency of grafts to the circumflex and right territories was lower and with a larger difference between groups favoring CCABG.

In the 250 stenotic or occluded grafts, the obstruction was observed at 121 proximal anastomoses, 65 shafts, and 96 distal anastomoses. In a high proportion of grafts with obstruction at the proximal anastomosis, the shaft and the distal anastomosis were graded as being "not sufficiently well visualized to decide."

As reported earlier, a total of 62 myocardial infarctions were diagnosed by the independent end point committee in the DOORS study. ${ }^{4}$ A total of 30 of these patients (19 randomized to OPCAB) underwent the follow-up coronary angiography at 6 months. Eleven OPCAB patients and 5 CCABG patients with myocardial infarction had at least 1 documented occluded graft. All the myocardial infarctions associated with documented occluded grafts occurred within 24 hours of surgery, except for 1 patient, who was diagnosed with myocardial infarction in the interval between 1 and 30 days after surgery.

The proportion of nonoccluded left internal thoracic artery grafts was $95 \%$ in both groups, with higher proportions of stenotic and occluded vein grafts and grafts of the radial artery or right internal thoracic artery.
A perioperative revision of the anastomosis was performed in 45 cases among the 1360 grafts that were later visualized. Eleven of these grafts $(24 \%)$ were either stenotic or occluded at follow-up. This figure was not statistically different from the fate at follow-up of the grafts in which no revision was performed $(P=.32)$.

\section{Native Coronary Arteries}

The native vessel was stenotic or closed $1 \mathrm{~cm}$ proximal to the anastomosis site in 58 of 177 cases $(33 \%)$ in which a proximal snare was applied during surgery and in 253 of 978 cases $(26 \%)$ in which it was not applied $(P=.06)$. With regard to the use of intracoronary shunts, the native vessel was stenotic or occluded proximal to the anastomosis in 140 of 470 cases $(30 \%)$ in which a shunt was applied versus 172 of 684 cases $(34 \%)$ in which it was not applied $(P=.08)$, and $1 \mathrm{~cm}$ distal to the anastomosis in 40 of 475 cases $(8 \%)$ after application of a shunt compared with 48 of 688 cases $(7 \%)$ in which a shunt was not used $(P=.44)$.

\section{Binomial Regression Analysis}

The results of the binomial regression model are given in Table 2. This analysis confirmed that graft patency was inferior in OPCAB patients compared with CCABG patients. Pedicled grafts performed better in terms of graft patency at follow-up than grafts with a proximal anastomosis on the aorta. Conversely, Y grafts tended to perform worse, although this difference was not statistically significant $(P=.09)$. From the crude data analysis, single grafts performed better than sequential grafts, but this difference was less apparent after taking into account that sequential 
TABLE 2. Risk difference analysis for graft obstruction, defined as either stenosis $>\mathbf{5 0} \%$ or occlusion

\begin{tabular}{|c|c|c|c|c|c|c|c|c|c|c|}
\hline & \multirow[b]{2}{*}{$\mathbf{N}$} & \multirow[b]{2}{*}{ Obstructed (\%) } & \multicolumn{4}{|c|}{ Crude analysis } & \multicolumn{4}{|c|}{ Multiply adjusted analysis } \\
\hline & & & RD & CI low & CI upper & $P$ value & RD & CI low & CI upper & $P$ value \\
\hline CCABG & 650 & 15.5 & \multicolumn{4}{|c|}{ (ref) } & \multicolumn{4}{|c|}{ (ref) } \\
\hline OPCAB & 710 & 21.0 & 5.4 & 0.9 & 10.0 & .02 & 4.6 & 3.8 & 8.8 & .033 \\
\hline \multicolumn{11}{|l|}{ Territory } \\
\hline LAD & 643 & 14.4 & \multicolumn{4}{|c|}{ (ref) } & \multicolumn{4}{|c|}{ (ref) } \\
\hline $\mathrm{Cx}$ & 318 & 21.7 & 7.2 & 2.0 & 12.4 & .01 & 5.3 & -1.5 & 12.2 & .128 \\
\hline $\mathrm{RCA}$ & 399 & 22.1 & 7.6 & 3.1 & 12.1 & .001 & 4.4 & -1.1 & 9.9 & .118 \\
\hline \multicolumn{11}{|l|}{ Proximal anastomosis site } \\
\hline Aorta & 648 & 19.6 & \multicolumn{4}{|c|}{ (ref) } & \multicolumn{4}{|c|}{ (ref) } \\
\hline Y graft & 251 & 27.1 & 7.5 & 0.7 & 14.3 & .03 & 6.8 & -1.1 & 14.8 & .09 \\
\hline Pedicled & 461 & 12.0 & -7.7 & -12.3 & -3.1 & .001 & -13.6 & -19.6 & -7.6 & $<.001$ \\
\hline \multicolumn{11}{|l|}{ Graft material } \\
\hline Saphenous vein & 694 & 20.2 & \multicolumn{4}{|c|}{ (ref) } & \multicolumn{4}{|c|}{ (ref) } \\
\hline Radial artery & 176 & 25.0 & 4.8 & -2.9 & 12.6 & .22 & -1.7 & -8.2 & 4.8 & .48 \\
\hline Left internal thoracic artery & 454 & 12.6 & -7.6 & -12.1 & -3.1 & .001 & 11.1 & 7.5 & 14.7 & $<.001$ \\
\hline Right internal thoracic artery & 36 & 25.0 & 4.8 & -10.0 & 19.6 & .52 & 9.8 & -2.5 & 22.2 & .12 \\
\hline Single graft & 649 & 14.5 & \multicolumn{4}{|c|}{ (ref) } & \multicolumn{4}{|c|}{ (ref) } \\
\hline Sequential graft, second anastomosis & 314 & 22.9 & 8.4 & 3.1 & 13.8 & .002 & 6.7 & 0.5 & 13.0 & .034 \\
\hline Sequential graft, third anastomosis & 269 & 18.6 & 4.1 & -1.2 & 9.4 & .13 & -0.8 & -7.1 & 5.5 & .072 \\
\hline Sequential graft, $>$ third anastomosis & 128 & 26.6 & 12.1 & 4.2 & 19.8 & .002 & 5.0 & -3.7 & 13.9 & .26 \\
\hline No revision & 1315 & 18.2 & \multicolumn{4}{|c|}{ (ref) } & \multicolumn{4}{|c|}{ (ref) } \\
\hline Revision & 45 & 24.4 & 6.3 & -6.2 & 18.7 & .324 & 6.3 & -4.9 & 17.6 & .27 \\
\hline
\end{tabular}

$R D$, Risk difference (\%); $C I$, confidence interval; $C C A B G$, conventional coronary artery bypass grafting; $O P C A B$, off-pump coronary artery bypass; $L A D$, left anterior descending artery; $C x$, circumflex artery; $R C A$, right coronary artery

grafts were usually placed in the circumflex and right coronary artery territories, where the patency tended to be inferior to that in the left anterior descending (LAD) territory. In the crude data analysis, the left internal thoracic artery (ITA) graft patency was significantly better than the other graft materials, but this was not the case after correcting for the fact that it was almost exclusively used for the more favorable LAD territory. In the post hoc analysis, the use of shunts did not significantly increase the risk of graft obstruction (risk difference $1.1 \%, 95 \%$ confidence interval, $-5.0 \%$ to $7.4 \%, P=.71$ ).

The propensity to attend the follow-up angiography was unevenly distributed among groups. In a logistic regression analysis including the randomization group, age, sex, left main coronary artery disease, left ventricular ejection fraction (LVEF), triple vessel disease, previous myocardial infarction, diabetes, hypertension, and smoking status, male patients were more prone to attend the follow-up (odds ratio, $0.53 ; 95 \%$ CI, $0.38-0.73, P<.001$ ). For OPCAB patients, younger patients, and patients with LVEF greater than $50 \%$, similar but weaker tendencies toward more frequent attendance were observed, all at a standard significance level less than $5 \%$ but not sufficiently marked to hold significance when corrected for multiple testing.

To account for this, the standard analyses of differences in risk of occlusion were supplemented by propensityweighted analyses, in which the propensity to attend follow-up was estimated using 2 different logistic models: 1 including all the abovementioned factors (Table E1, part A) and 1 including all the abovementioned factors and allowing interaction between the randomization group and the other factors (Table E1, part B). No post hoc elimination for nonsignificance was performed.

Propensity weighting entailed a slightly lower overall estimate of graft patency. This is not unexpected, because some of the preoperative characteristics predicting attendance (low age, high LVEF) are also plausible predictors for graft patency. However, as the implied selection was not double skewed with respect to the perioperative parameters studied, accounting for propensity to attend follow-up did not affect the overall results or conclusions.

\section{DISCUSSION}

Follow-up angiographic data from 1 of the largest randomized comparisons of OPCAB and CCABG is presented. Through a uniform protocol, potential effects caused by differences in heparinization protocols in earlier studies were eliminated. We hypothesized that this design would improve graft patency in the OPCAB group by lessening the degree of hypercoagulability. However, contrary to our expectations, we found that graft patency was poorer after OPCAB compared with CCABG.

Several randomized studies have confirmed that lower graft patency results from OPCAB compared with CCABG surgery, although these studies did not account sufficiently 
for differences in antithrombotic regimens. ${ }^{14,16-18}$ In our study, impaired graft patency was most evident when not only considering the proportion of totally occluded grafts but also the number of stenotic grafts by using the FitzGibbon score, ${ }^{26}$ as also seen in the ROOBY trial. ${ }^{16}$ Although graft occlusion may, theoretically, be caused by hypercoagulability, stenosis is more likely to be caused by technical anastomotic issues and operator experience has been suggested to be an important variable for graft patency after OPCAB. Undoubtedly, performing an anastomosis on a beating heart is more technically challenging than on the cardioplegic heart and may require a longer learning curve. In particular, performing the anastomosis to the circumflex area of the heart during OPCAB requires experience. In the present study, the participating surgeons were required to have performed at least $25 \mathrm{OPCAB}$ procedures involving grafts to the circumflex area before being certified to participate. Specifically, 10 of the 12 participating surgeons had performed more than the $100 \mathrm{OPCAB}$ procedures that were required to participate in the CORONARY study and we consider it likely that their learning curve had reached a plateau and that our findings were caused by inherent weakness of the OPCAB procedure rather than by inexperience of the surgeons.

We confirm the findings from earlier trials reporting lower graft patency as well as fewer grafts being performed with OPCAB than with CCABG surgery. ${ }^{14,16-18}$ At present, it is not clear whether this difference has effects on patient symptoms, life expectancy, or quality of life. Long-term follow-up from more studies is warranted to elucidate this question. However, the fact that the ROOBY investigators found a higher risk of cardiac death within 1 year postoperatively in patients operated with OPCAB compared with $\mathrm{CCABG},{ }^{3}$ as well as a higher risk of cardiovascular events in patients with occluded grafts, ${ }^{16}$ are causes for concern. The same applies to the finding of a higher need for coronary reinterventions in the OPCAB groups of the both the CORONARY and ROOBY trials. ${ }^{16,18}$ Perioperative myocardial infarctions may be caused either by graft dysfunction or by inadequate perioperative myocardial protection. In the present study, graft occlusion tended to be more frequent in patients who had a myocardial infarction after OPCAB than in patients who had a myocardial infarction after CCABG, possibly pointing toward different infarct mechanisms.

The use of a looped prolene suture or silicone snare to occlude the target coronary artery distally to the anastomosis has been suspected to cause damage to the vessel. ${ }^{27}$ In the post hoc multivariate analysis including use of snares and shunts, the use of a proximal snare was an independent predictor of graft failure. We believe that this difference may be caused, in part, by selection bias as surgeons tend to use the proximal occlusion technique in cases where a large amount of competitive flow is present and the latter is known to be a predictor of graft occlusion. ${ }^{28}$ Although experimental studies and human studies using scanning electron microscopy have shown that the use of intracoronary shunts causes damage to the coronary endothelium, ${ }^{29}$ the present study did not indicate that the use of shunts causes stenosis of the native coronary artery at the site of application distal to the anastomosis.

Although, in our crude analysis, the left ITA grafts performed better than the other grafts, it is interesting that the multivariate analysis did not confirm this finding. Even in the absence of randomized controlled trials, it is widely accepted that the left ITA is the best available graft material. ${ }^{30}$ Recent studies have not convincingly demonstrated a similar advantage from using the biologically similar right ITA compared with radial artery or vein graft material for other coronary territories than LAD. ${ }^{31}$ Still, caution should be taken about drawing too firm conclusions from this incidental finding in the present study.

As we have reported earlier, a higher amount of perioperative bleeding was found in OPCAB patients than in CCABG patients in the DOORS study. ${ }^{4}$ This finding is in contrast to the results of most earlier trials, which reported that bleeding was reduced by avoiding cardiopulmonary bypass. $^{8-10}$ It can be suspected that this difference is influenced by the higher dose of heparin used in the OPCAB group in the present study. Because we did not find that this drawback was balanced by a decrease in the difference in graft patency between groups, we do not recommend the practice of full perioperative heparinization to be adopted. Whether dual antiplatelet therapy should be administered to all patients undergoing OPCAB and CCABG, and the optimal duration of such therapy, if appropriate, requires further study. However, dual antiplatelet therapy (aspirin and clopidogrel) is recommended for 12 months after non-ST segment elevation acute coronary syndromes, that is, irrespective of coronary bypass surgery during this period, in patients who are not at increased risk of bleeding. ${ }^{32}$

In conclusion, in a randomized setting, we found that OPCAB patients received fewer grafts and had inferior graft patency than patients operated on-pump even with identical heparinization protocols. We did not find that the use of intracoronary shunts caused damage to the native vessels. Binomial regression analysis showed that the use of cardiopulmonary bypass, pedicled grafts, and position on the LAD territory were positive predictors of graft patency.

\section{Limitations}

Only $56 \%$ of the patients who survived the first 6 months were willing or able to undergo the follow-up coronary angiography. As indicated above, some selection bias was present with regard to the propensity of the patients to 
attend coronary angiography. However, propensity weighting did not change the overall results or conclusions.

\section{References}

1. Wijeysundera DN, Beattie WS, Djaiani G, Rao V, Borger MA, Karkouti K, et al. Off-pump coronary artery surgery for reducing mortality and morbidity: metaanalysis of randomized and observational studies. J Am Coll Cardiol. 2005;46: 872-82.

2. Lamy A, Devereaux PJ, Prabhakaran D, Taggart DP, Hu S, Ernesto Paolasso E, et al; for the CORONARY Investigators. Off-pump or on-pump coronary-artery bypass grafting at 30 days. $N$ Engl J Med. 2012;366:1489-97.

3. Shroyer AL, Grover FL, Hattler B, Collins JF, McDonald GO, Kozora E, et al. On-pump versus off-pump coronary-artery bypass surgery. $N$ Engl J Med. 2009;361:1827-37.

4. Houlind K, Kjeldsen BJ, Madsen SN, Rasmussen BS, Holme SJ, Nielsen PH, et al; DOORS Study Group. On-pump versus off-pump coronary artery bypass surgery in elderly patients: results from the Danish on-pump versus off-pump randomization study. Circulation. 2012;125:2431-9.

5. Nesher N, Frolkis I, Vardi M, Sheinberg N, Bakir I, Caselman F, et al. Higher levels of serum cytokines and myocardial tissue markers during on-pump versus off-pump coronary artery bypass surgery. J Card Surg. 2006;21:395-402.

6. Onorati F, Rubino AS, Nucera S, Foti D, Sica V, Santini F, et al. Offpump coronary artery bypass surgery versus standard linear or pulsatile cardiopulmonary bypass: endothelial activation and inflammatory response. Eur J Cardiothorac Surg. 2010;37:897-904.

7. Gu YJ, Mariani MA, van Oeveren W, Grandjean JG, Boonstra PW. Reduction of the inflammatory response in patients undergoing minimally invasive coronary artery bypass grafting. Ann Thorac Surg. 1998;65:420-4.

8. Angelini GD, Taylor FC, Reeves BC, Ascione R. Early and midterm outcome after offpump and on-pump surgery in Beating Heart Against Cardioplegic Arrest Studies (BHACAS 1 and 2): a pooled analysis of two randomised controlled trials. Lancet. 2002:359:1194-9.

9. Nathoe HM, Dijk D, Jansen EWL, Suyker WJL, Diephuis JC, Boven WJ, et al. A comparison of on-pump and off-pump coronary bypass surgery in low-risk patients. N Engl J Med. 2003;348:394-402.

10. Puskas JD, Williams WH, Duke PG, Staples JR, Glas KE, Marshall JJ, et al. Offpump coronary artery bypass grafting provides complete revascularization with reduced myocardial injury, transfusion requirements, and length of stay: a prospective randomized comparison of two hundred unselected patients undergoing off-pump versus conventional coronary artery bypass grafting. J Thorac Cardiovasc Surg. 2003;125:797-808.

11. Khan NE, De Souza A, Mister R, Flather M, Clague J, Davies S, et al. A randomized comparison of off-pump and on-pump multivessel coronary-artery bypass surgery. N Engl J Med. 2004;350:21-8.

12. van Dijk D, Nierich AP, Jansen EWL, Nathoe HM, Suyker WJL, Diephuis JC, et al; for the Octopus Study Group. Early outcome after off-pump versus on-pump coronary bypass surgery: results from a randomized study. Circulation. 2001;104:1761-6.

13. Puskas JD, Williams WH, Mahoney EM, Huber PR, Block PC, Duke PG, et al. Off-pump vs conventional coronary artery bypass grafting: early and 1 year graft patency, cost, and quality-of-life outcomes. A randomized trial. JAMA. 2004; 291:1841-9.

14. Straka Z, Widimsky P, Jirasek K, Stros P, Votava J, Vanek T, et al. Off-pump versus on-pump coronary surgery: final results from a prospective randomized study PRAGUE-4. Ann Thorac Surg. 2004;77:789-93.

15. Houlind K, Kjeldsen BJ, Madsen SN, Rasmussen BS, Holme SJ, Pallesen PA, et al; DOORS Study Group. OPCAB surgery is cost-effective for elderly patients. Scand Cardiovasc J. 2013;47:185-92.
16. Hattler B, Messenger JC, Shroyer AL, Collins JF, Haugen SJ, Garcia JA, et al for the Veterans Affairs Randomized On/Off Bypass (ROOBY) Study Group. Off-pump coronary artery bypass surgery is associated with worse arterial and saphenous vein graft patency and less effective revascularization results from the Veterans Affairs Randomized On/Off Bypass (ROOBY) trial. Circulation. 2012; $125: 2827-35$

17. Møller CH, Perko MJ, Lund JT, Andersen LW, Kelbæk H, Madsen JK, et al. Graft patency after off-pump versus on-pump coronary artery surgery in high-risk patients. Scand Cardiovasc J. 2010;44:161-7.

18. Uva MS, Cavaco S, Oliveira AG, Matias F, Silva C, Mesquita A, et al. Early graft patency after off-pump and on-pump coronary bypass surgery: a prospective randomized study. Eur Heart J. 2010;31:2492-9.

19. Ascione R, Williams S, Lloyd CT, Sundaramoorthi T, Pitsis AA, Angelini GD. Reduced postoperative blood loss and transfusion requirement after beatingheart coronary operations: a prospective randomized study. Ann Thorac Surg. 1999;68:493-8.

20. Harker LA, Malpass TW, Branson HE, Hessel EA, Slichter SJ. Mechanism of abnormal bleeding in patients undergoing cardiopulmonary bypass: acquired transient platelet dysfunction associated with selective alpha-granule release. Blood. 1980;56:824-34.

21. Kon ZN, Kwon MH, Collins MJ, Kallam S, Sangrampurkar R, Ozeki T, et al Off-pump coronary artery bypass leads to a regional hypercoagulable state not detectable using systemic markers. Innovations (Phila). 2006;1:232-8.

22. Mariani MA, Gu YJ, Boonstra PW, Grandjean JG, van Oeveren W, Ebels T Procoagulant activity after off-pump coronary operation: is the current anticoagulation adequate? Ann Thorac Surg. 1999;67:1370-5.

23. Thourani VH, Guyton RA. Graft patency after off-pump coronary artery bypass surgery. Circulation. 2012;125:2806-8.

24. Deo SV, Dunlay SM, Shah IK, Altarabsheh SE, Erwin PJ, Boilson BA, et al. Dual anti-platelet therapy after coronary artery bypass grafting: is there any benefit? A systematic review and meta-analysis. J Card Surg. 2013;28: 109-16.

25. Houlind K, Kjeldsen BJ, Madsen SN, Rasmussen BS, Holme SJ, Schmidt TA, et al; DOORS Study Group. The impact of avoiding cardiopulmonary by-pass during coronary artery bypass surgery in elderly patients: the Danish On-pump Off-pump Randomization Study (DOORS). Trials. 2009; $10: 47-55$.

26. FitzGibbon GM, Leach AJ, Kafka HP, Keon WJ. Coronary bypass graft fate: long term angiographic study. J Am Coll Cardiol. 1991;17:1075-80.

27. Alessandrini F, Gaudino M, Glieca F, Luciani N, Piancone FL, Zimarino M, et al Lesions of the target vessel during minimally invasive myocardial revascularization. Ann Thorac Surg. 1997;64:1349-53.

28. Nakajima H, Kobayashi J, Toda K, Fujita T, Shimahara Y, Kasahara Y, et al Angiographic evaluation of flow distribution in sequential and composite grafts for three-vessel disease. Eur J Cardiothorac Surg. 2012;41:763-9.

29. Hangler H, Mueller L, Rottmann E, Antretter H, Pfaller K. Shunt or snare: coronary endothelial damage due to hemostatic devices for beating heart coronary surgery. Ann Thorac Surg. 2008;86:1873-7.

30. Loop FD, Lytle BW, Cosgrove DM, Stewart RW, Goormastic M, Williams GW, et al. Influence of the internal-mammary-artery graft on 10-year survival and other cardiac events. N Engl J Med. 1986;314:1-6.

31. Buxton BF, Ruengsakulrach P, Fuller J, Rosalion A, Reid CM, Tatoulis J. The right internal thoracic artery graft - benefits of grafting the left coronary system and native vessels with a high grade stenosis. Eur J Cardiothorac Surg. 2000;18: 255-61.

32. Sørensen R, Abildstrøm SZ, Hansen PR, Hvelplund A, Andersson C, Charlot M, et al. Efficacy of post-operative clopidogrel treatment in patients revascularized with coronary artery bypass grafting after myocardial infarction. J Am Coll Cardiol. 2011;57:1202-9. 


\section{APPENDIX E1. THE DOORS STUDY GROUP Investigators}

Kim Houlind, MD, PhD (Chairman), Bo Juul Kjeldsen, $\mathrm{MD}, \mathrm{PhD}$, Susanne Madsen, MD, Bodil Steen Rasmussen, MD, PhD, Susanne Holme, MD, Poul Erik Mortensen, MD.

\section{Steering Committee}

Poul Erik Mortensen, MD (Chairman), Vibeke Hjortdal, MD, DMSc, PhD, Gert Lerbjerg, MD, Uffe Niebuhr, MD, Soren Aggestrup, MD, Susanne Holme, MD, Per Hostrup Nielsen, MD, Jorn Sollid, MD, Jorgen Videbæk, MD, DMSc, Kim Houlind, MD, PhD.

\section{Ethical and Safety Committee}

Paul Sergeant, MD, PhD (Chairman), Elisabeth Stahle, MD, DMSc, Patrick Wouters, MD.

\section{End Point Committee}

Peter Kildeberg Paulsen, MD, DMSc (Chairman), Christian Hassager, MD, DMSc, Ib Chr. Klausen, MD, DMSc, Grethe Andersen, MD, DMSc, Per Meden, MD, Boris Modrau, MD.

\section{Statistical Group}

Henrik Toft Sørensen, MD, DMSc, Søren Paaske Johnsen, MSc PhD, Niels Trolle Andersen, MSc, PhD, Morten Fenger-Grøn, MSc.

\section{Surgical Group}

Jan Jesper Andreasen, MD, PhD, Poul Erik Haahr, MD, John Christensen, MD, Jens Grønlund, MD, Susanne Holme, MD, Per Hostrup Nielsen, MD, Mogens Harrits Jepsen, MD, Bo Juul Kjeldsen, MD, PhD, Susanne Madsen, MD, Poul Erik Mortensen, MD, Peter Pallesen, MD, Jørn Sollid, MD.

\section{Invasive Cardiology Group}

Jan Ravkilde, MD, DMSc, Jens Aaroe, MD, DMSc, Peter Riis Hansen, MD, DMSc, Henrik Steen Hansen, MD, DMSc, Dorthe Dalsgaard, MD, Henrik Munkholm, MD.

\section{Committee on Health Economics}

Lars Ehlers, MSc, PhD, Søren Jepsen Bech, MSc, Kristian Kidholm, MSc, PhD, Jørgen Lauridsen, MSc, PhD. 
TABLE E1. The propensity to attend follow-up was estimated using 2 different logistic models (including randomization group, age, sex, left main coronary artery disease, left ventricular ejection fraction, triple vessel disease, previous myocardial infarction, diabetes, hypertension, and smoking status), which differed by either not allowing or allowing interaction between the randomization group and the other factors

\begin{tabular}{|c|c|c|c|c|c|c|c|c|}
\hline & \multicolumn{4}{|c|}{ Crude analysis } & \multicolumn{4}{|c|}{ Multiply adjusted analysis } \\
\hline & RD & CI low & CI upper & $P$ value & RD & CI low & CI upper & $P$ value \\
\hline \multicolumn{9}{|c|}{ A: Allowing interaction between the randomization group and the other factors } \\
\hline CCABG & \multicolumn{4}{|c|}{ (ref) } & \multicolumn{4}{|c|}{ (ref) } \\
\hline OPCAB & 6.1 & 1.5 & 10.8 & .01 & 5.2 & 0.8 & 9.5 & .02 \\
\hline \multicolumn{9}{|l|}{ Territory } \\
\hline LAD & \multicolumn{4}{|c|}{ (ref) } & \multicolumn{4}{|c|}{ (ref) } \\
\hline $\mathrm{Cx}$ & 7.7 & 2.1 & 13.3 & .01 & 6.1 & -1.3 & 13.6 & .13 \\
\hline RCA & 8.7 & 4.0 & 13.5 & $<.001$ & 5.7 & 0.0 & 11.5 & .048 \\
\hline \multicolumn{9}{|l|}{ Proximal anastomosis site } \\
\hline Aorta & \multicolumn{4}{|c|}{ (ref) } & \multicolumn{4}{|c|}{ (ref) } \\
\hline Y graft & 7.5 & 0.7 & 14.3 & .03 & 5.6 & -0.02 & 13.4 & .16 \\
\hline Pedicled & -8.5 & -13.4 & -3.7 & $<.001$ & -13.4 & -19.4 & -7.4 & $<.001$ \\
\hline \multicolumn{9}{|l|}{ Graft material } \\
\hline Saphenous vein & \multicolumn{4}{|c|}{ (ref) } & \multicolumn{4}{|c|}{ (ref) } \\
\hline Radial artery & 4.1 & -3.7 & 12.1 & .30 & -1.6 & -8.4 & 5.2 & .52 \\
\hline Left internal thoracic artery & -8.4 & -13.2 & -3.8 & $<.001$ & 11.2 & 7.3 & 15.0 & $<.001$ \\
\hline Right internal thoracic artery & 3.0 & -10.7 & 16.8 & .67 & 9.1 & -2.9 & 21.2 & .14 \\
\hline Single graft & \multicolumn{4}{|c|}{ (ref) } & \multicolumn{4}{|c|}{ (ref) } \\
\hline Sequential graft, second anastomosis & 9.6 & 3.8 & 15.4 & .001 & 7.8 & 1.2 & 14.3 & .02 \\
\hline Sequential graft, third anastomosis & 3.8 & -1.7 & 9.3 & .18 & -1.5 & -7.9 & 4.8 & .63 \\
\hline Sequential graft, $>$ third anastomosis & 12.3 & 4.5 & 20.2 & .002 & 4.5 & -3.8 & 13.9 & .26 \\
\hline No revision & \multicolumn{4}{|c|}{ (ref) } & \multicolumn{4}{|c|}{ (ref) } \\
\hline Revision & 4.1 & -8.3 & 16.5 & .51 & 3.8 & -6.7 & 14.4 & .47 \\
\hline \multicolumn{9}{|c|}{ B: Not allowing interaction between the randomization group and the other factors } \\
\hline CCABG & \multicolumn{4}{|c|}{$(\mathrm{ref})$} & \multicolumn{4}{|c|}{ (ref) } \\
\hline OPCAB & 5.8 & 1.1 & 10.5 & .02 & 5.1 & 0.8 & 9.5 & .02 \\
\hline \multicolumn{9}{|l|}{ Territory } \\
\hline LAD & & & ef) & & & & & \\
\hline $\mathrm{Cx}$ & 7.5 & 2.0 & 13.0 & .01 & 5.4 & -1.7 & 12.5 & .14 \\
\hline RCA & 8.0 & 3.3 & 12.8 & .001 & 4.7 & -0.9 & 10.4 & .10 \\
\hline Proximal anastomosis site & & & & & & & & \\
\hline Aorta & & & ef) & & & & & \\
\hline Y graft & 6.2 & -0.01 & 13.2 & .09 & 4.5 & -0.04 & 12.5 & .27 \\
\hline Pedicled & -8.4 & -13.2 & -3.6 & $<.001$ & -15.3 & -21.5 & -9.1 & $<.001$ \\
\hline Graft material & & & & & & & & \\
\hline Saphenous vein & & & ef) & & & & & \\
\hline Radial artery & 4.2 & -3.9 & 12.4 & .31 & -0.2 & -6.9 & 6.5 & .96 \\
\hline Left internal thoracic artery & -8.1 & -12.9 & -3.3 & .001 & 12.7 & 8.9 & 16.3 & $<.001$ \\
\hline Right internal thoracic artery & 2.9 & -11.0 & 16.8 & .68 & 10.7 & -1.9 & 23.3 & .10 \\
\hline Single graft & & & ef) & & & & & \\
\hline Sequential graft, second anastomosis & 9.5 & 3.6 & 15.4 & .002 & 7.7 & 0.9 & 14.5 & .03 \\
\hline Sequential graft, third anastomosis & 3.9 & -1.6 & 9.5 & .16 & -0.9 & -7.4 & 5.4 & .76 \\
\hline Sequential graft, $>$ third anastomosis & 12.5 & 4.7 & 20.2 & .002 & 5.6 & -3.1 & 14.3 & .21 \\
\hline No revision & & & ef) & & & & & \\
\hline Revision & 7.0 & -6.3 & 20.2 & .30 & 6.7 & -5.1 & 18.5 & .26 \\
\hline
\end{tabular}

$R D$, Risk difference (\%); $C I$, confidence interval; $C C A B G$, conventional coronary artery bypass grafting; $O P C A B$, off-pump coronary artery bypass; $L A D$, left anterior descending; $C x$, circumflex artery; $R C A$, right coronary artery. 